\title{
Induction of the Mx protein of rainbow trout Oncorhynchus mykiss in vitro and in vivo with poly I:C dsRNA and infectious hematopoietic necrosis virus
}

\author{
Grant D. Trobridge, Pinwen P. Chiou, Carol H. Kim, JoAnn C. Leong*
}

Department of Microbiology and Center for Salmon Disease Research, Oregon State University, Corvallis, Oregon 97331-3804, USA

\begin{abstract}
Expression of the Mx protein of rainbow trout was analyzed after induction by poly $\mathrm{I}: \mathrm{C}$ dsRNA and infectious hematopoietic necrosis virus (IHNV). Poly l:C dsRNA-treated rainbow trout gonad (RTG-2) cells expressed Mx protein that was detectable by immunoblot analysis at $24 \mathrm{~h}$ post induction. Increased expression was observed at $48 \mathrm{~h}$ and then declined by $72 \mathrm{~h}$ post induction. In contrast, IHNV was not an efficient inducer of $\mathrm{Mx}$ protein in cells in culture. An immunocytochemical assay was also established to detect $\mathrm{Mx}$ proteins after transient transfection of chinook salmon embryo (CHSE-214) cells with trout Mx cDNA expression clones. Using these same techniques, endogenous $\mathrm{Mx}$ protein was detected in RTG-2 cells induced with 5 and $50 \mu \mathrm{g} \mathrm{ml}^{-1}$ of poly I:C dsRNA at $48 \mathrm{~h}$ post induction. In vivo, the appearance of Mx protein in rainbow trout after infection with IHNV (isolated at Rangen Research, Hagerman, ID, USA) was demonstrated in the immunoblots of kidney extracts of 4 out of 4 fish at $2 \mathrm{~d}$ post infection. Immunohistochemical staining of the kidney tissue from 3 out of 3 rainbow trout fry infected with the RB-76 strain of IHNV (isolated at Rounded Butte Hatchery, OR, USA) confirmed the production of $\mathrm{Mx}$ protein in the kidney tubules at $2 \mathrm{~d}$ post infection. These results suggest that $\mathrm{Mx}$ is a useful marker for the induction of fish interferon.
\end{abstract}

KEY WORDS: MX - Interferon P Poly I:C $\cdot$ Infectious hematopoietic necrosis virus $\cdot$ Rainbow trout

\section{INTRODUCTION}

The interferons (IFNs) provide vertebrates with a first line of defense against viral infection. These cytokines are produced by virus-infected cells and stimulate the production of IFN-induced proteins in neighboring, uninfected cells. These induced IFNregulated proteins (IRPs), in turn, confer antiviral resistance upon the uninfected cells. The IRPs that have been identified include P1 kinase, 2'-5' oligoadenylate synthetase, and the Mx proteins; all inhibit intracellular viral replication (Staeheli et al. 1986, Meurs et al. 1990, Koromilas et al. 1992). The characterization of the $\mathrm{Mx}$ proteins in fish and their induction in vivo and in vitro is the subject of this report.

There have been several reports characterizing IFNlike activity in fish cells in vitro and in vivo. Gravell \&

-Addressee for correspondence. E-mail: leongj@bcc.orst.edu
Malsberger (1965) first demonstrated the in vitro production of fish IFN in fathead minnow Pimephalus promelas cells when exposed to infectious pancreatic necrosis virus (IPNV). In vitro induction of a fish IFN has been reported by several investigators (Beasley \& Sigel 1967, Oie \& Loh 1971, de Sena \& Rio 1975, MacDonald \& Kennedy 1979, Sano \& Nagakura 1982, Tengelsen et al. 1989) and all of the studies have suggested that IFN is an important component of the innate immune system of fish. The investigators de Kinkelin \& Dorson (1973) showed that trout injected with viral hemorrhagic septicemia virus (VHSV) produced an IFN-like substance in the sera that was able to confer resistance to IPNV, VHSV, and IHNV in rainbow trout gonad (RTG-2) cells. Eaton (1990) induced IFN production in chum Oncorhynchus keta and sockeye $O$. nerka salmon. The induced IFN stimulated an antiviral response that resulted in decreased IHNV titre, decreased cumulative mortalities, and delayed virus replication in IHNV-challenged salmon. 
In mammals, the IFN-induced $M x$ proteins are involved in resistance to influenza viruses (Staeheli et al. 1986, Frese et al. 1995. Thimme et al. 1995), the rhabdovirus vesicular stomatitis virus (VSV) (Meier et al. 1990), the paramyxovirus measles (Schneider-Schaulies et al. 1994), and members of the Bunyaviridae (Frese et al. 1996). The Mx proteins are characteristically 70 to $80 \mathrm{kDa}$ in size and contain GTPase activity (for review see Staeheli \& Haller 1987. Arnheiter \& Meier 1990). A GTP binding motif, found in all Mx proteins, has been shown to be essential for GTP binding and required for the antiviral activity of human MxA and murine $\mathrm{Mx} 1$; this motif is also found in the trout Mx proteins (Pitossi et al. 1993, Melen \& Julkunen 1994). These Mx proteins do not interfere with virus adsorption, penetration, or transport of influenza nucleocapsids into the nucleus (Horisberger et al. 1980, Meyer \& Horisberger 1984, Broni et al. 1990), but they do reduce the primary transcription of influenza in the nucleus (Krug et al. 1985). Using 3T3 cells that express human MxA constitutively, Pavlovic et al. (1992) found that influenza viral mRNAs accumulated in the nucleus to normal levels, but viral protein synthesis and genome amplification were strongly inhibited. The exact mechanisms involved in the inhibition remain unknown. Other $\mathrm{Mx}$ proteins interfere with the replication of different viruses by other less well understood mechanisms (Frese et al. 1995). In order to examine the potential role of fish Mx proteins in the antiviral response of fish, we initiated cloning and characterization of the $\mathrm{Mx}$ genes in the trout genome.

We have previously reported the cloning of 3 trout Mx cDNA clones from rainbow trout cells (Trobridge \& Leong 1995) and generated antisera to the trout $\mathrm{Mx}$ proteins (Trobridge et al. 1997). Here, we further characterize the induction of $\mathrm{Mx}$ protein by poly $\mathrm{I}: \mathrm{C}$ dsRNA and IHNV in trout. $\mathrm{Mx}$ protein has been used as a marker for IFN production in human studies (Towbin et al. 1992, Oh et al. 1994). Using the artificial IFN inducer, poly I:C dsRNA, and the rhabdovirus IHNV we demonstrate that trout $\mathrm{Mx}$ proteins may be used as markers for the IFN response of trout in vitro and in vivo.

\section{MATERIALS AND METHODS}

Cell lines and viruses. The chinook salmon embryo (CHSE-214, Fryer et al. 1965) and rainbow trout gonad (RTG-2, Wolf \& Quimby 1962) cell lines used in this study were obtained from J. L. Fryer, Oregon State University, Corvallis (OR, USA) (Fryer et al. 1965). The cells were grown as monolayers in minimal essential medium (MEM, Gibco-BRL, Gaithersburg, MD, USA) supplemented with $10 \%$ fetal bovine serum (FBS) and
2 mM L-glutamine (MEM-10). For virus propagation, CHSE-214 cells were supplemented with $5 \%$ FBS, $2 \mathrm{mM}$ L-glutamine, $14 \mathrm{mM}$ HEPES (N-2-Hydroxyethylpiperazine- $\mathrm{N}^{\prime}$-2-ethanesulfonic acid, $\mathrm{pH}$ 7.8), $100 \mathrm{IU}$ $\mathrm{ml}^{-1}$ penicillin $\mathrm{G}, 100 \mu \mathrm{g} \mathrm{ml}^{-1}$ streptomycin and $0.25 \mu \mathrm{g}$ $\mathrm{ml}^{-1}$ amphotericin B. The RB-4 IHNV used for viral induction of $\mathrm{Mx}$ in vitro was isolated in 1975 from an adult steelhead trout at the Round Butte Hatchery in Oregon (USA).

CHSE-214 cells were infected with IHNV at a multiplicity of infection (MOI) of 0.001 and incubated at $16^{\circ} \mathrm{C}$ for $7 \mathrm{~d}$. At that time the tissue culture supernatant fluid was harvested and centrifuged at $2500 \times g$ for $10 \mathrm{~min}$ at $4^{\circ} \mathrm{C}$, then filtered through a $0.22 \mu \mathrm{m}$ low protein binding filter (Gelman, Ann Arbor, MI, USA). The cell-free supernatant contained $7.5 \times 10^{6}$ tissue culture infective $50 \%$ doses per $\mathrm{ml}\left(\mathrm{TCID}_{50} \mathrm{ml}^{-1}\right)$. The Rangen isolate of IHNV used for in vivo induction of $\mathrm{Mx}$ protein detected by immunoblot was isolated from dead rainbow trout fry at the International Aquaculture Research Center (Rangen Research), Hagerman, Idaho, USA. The RB-76 strain of IHNV used for immunohistochemical localization of IHNV in fish tissue was isolated from moribund steelhead (O. mykiss) fry from an epizootic in 1976 at Round Butte Hatchery. To produce stocks used for challenge, virus was grown on CHSE214 cells which had been infected when the monolayers were $90 \%$ confluent.

In vitro inductions of $\mathbf{M x}$ protein. For immunoblot analysis of salmonid $\mathrm{Mx}$ protein induced by poly I:C dsRNA, RTG-2 cells were plated in 12-well plates. Confluent monolayers were washed with MEM without FBS (MEM-0) and treated with control MEM-0, $50 \mu \mathrm{g} \mathrm{ml}^{-1}$ poly I:C (Pharmacia, Piscataway, NJ, USA) in MEM-0, or IHNV at a MOI of 0.1 in MEM-0, for 24, 48 , and $72 \mathrm{~h}$. At each time point, the monolayer was washed twice with PBS and $200 \mu$ l of $2 \times$ SDS (sodium dodecyl sulphate) loading buffer was added to each well $[2 \times$ loading buffer is $125 \mathrm{mM}$ Tris- $\mathrm{HCl}(\mathrm{pH}$ 6.8), $2 \%$ SDS, $10 \%$ glycerol, and 5\% 2-mercaptoethanol]. The loading buffer with sample was removed, boiled for $3 \mathrm{~min}$, and frozen until analysis by SDS-PAGE (polyacrylamide gel electrophoresis). For immunocytochemistry, RTG-2 cells were plated in 6-well plates at $50 \%$ confluency. After overnight attachment, cells were washed in MEM-0 and treated with poly I:C at 0 (control), 5, and $50 \mu \mathrm{g} \mathrm{ml}^{-1}$ in $2 \mathrm{ml}$ MEM-0 for $48 \mathrm{~h}$.

In vivo induction of $\mathrm{Mx}$ by IHNV. Induction detected by immunoblot: Rainbow trout, average weight $2.2 \mathrm{~g}$, were held in $18.927 \mathrm{l}$ (5 gallons US) aquaria at $12^{\circ} \mathrm{C}$ with a flow rate of $0.6461 \mathrm{~min}^{-1}(0.25$ gallons $\left.\mathrm{min}^{-1}\right)$. Twenty fish were challenged with IHNV (Rangen) by immersion for $5 \mathrm{~h}$ in $10^{5} \mathrm{TCID}_{50}$. Twenty control fish were mock challenged with uninfected tissue culture supernatant fluid. The IHNV isolate used 
at this dose is known to cause high mortality. Approximately 2 to $10 \mathrm{mg}$ of liver and kidney were removed at 0,2 , and $4 \mathrm{~d}$ post challenge. The tissues were broken up by maceration with a pipette tip in $200 \mu$ of $2 \times$ loading buffer (see 'In vitro inductions of Mx protein'). Samples were then boiled for $5 \mathrm{~min}$ and frozen until assayed.

Induction detected by immunohistochemistry: Rainbow trout fry (average weight $0.5 \mathrm{~g}$ ) were used for the waterborne challenge. Fish were exposed to $10^{5}$ plaque forming units (PFU) $\mathrm{ml}^{-1}$ of the IHNV strain RB-76. The fish were exposed by static immersion for $6 \mathrm{~h}$ at $13^{\circ} \mathrm{C}$. A majority of the fish that would ultimately die began to show clinical signs of disease at $9 \mathrm{~d}$ post exposure. These signs were distended abdomen, petechial hemorrhages, and a whirling form of swimming. Moribund fish were collected and fixed in 10\% buffered formalin and embedded in Paraplast paraffin (Oxford Labware, St. Louis, MO, USA). Embedded fish were sliced sagittally and $6 \mu \mathrm{m}$ sections were fixed at $40^{\circ} \mathrm{C}$ overnight onto slides coated with $0.1 \%$ gelatin and $0.1 \%$ chromic potassium sulfate.

Western blot analysis. All samples were electrophoresed in $10 \%$ polyacrylamide gels and transferred to Optitran supported nitrocellulose membranes (Schleicher \& Schuell, Keene, NH, USA) using a BioRad Miniprotean transfer apparatus. Blots were blocked overnight in $5 \%$ nonfat dry milk in Tris buffered saline (TBS; $50 \mathrm{mM}$ tris, $1 \mathrm{mM}$ EDTA, $8.7 \% \mathrm{NaCl}^{\mathrm{pH}} 8.0$ ) at $4^{\circ} \mathrm{C}$. All subsequent steps were performed at room temperature.

In vitro western blot analysis: For in vitro analysis of RTG-2 Mx protein, $15 \mu$ l samples were loaded per lane. After electrophoresis and transfer, the membrane was incubated in $25 \mathrm{ml}$ of purified polyclonal rabbit anti-RBTMx IgG (Trobridge et al. 1996a) at $5 \mu \mathrm{g} \mathrm{ml}^{-1}$ IgG with $1 \%$ BSA (bovine serum albumin) and $0.02 \%$ Tween 20 for $1 \mathrm{~h}$. The membrane was washed $4 \times$ with $100 \mathrm{ml}$ of TBS with $1 \% \mathrm{BSA}$ and $0.02 \%$ Tween 20 . The membrane was then incubated with $1 \mu \mathrm{g} \mathrm{ml}^{-1}$ of mouse anti rabbit-alkaline phosphatase (Promega, Madison, WI, USA) for $1 \mathrm{~h}$ in TBS-0.02\% Tween 20. The membrane was washed $4 \times$ in $100 \mathrm{ml}$ TBS-0.02\% Tween 20 and incubated in alkaline phosphatase (AP) substrate using the Kirkegaard-Perry (Gaithersburg, MD) One Step detection kit.

In vivo western blot analysis: For in vivo analysis of both Mx protein and IHNV, $10 \mu$ lof the kidney and the liver tissue extracts in SDS-PAGE loading buffer were loaded onto separate lanes. Because of the increased sensitivity, and consequent increased background of chemiluminescent detection, the procedures were modified as follows. Blots were incubated with $25 \mathrm{ml}$ of $2 \mu \mathrm{g} \mathrm{ml} \mathrm{m}^{-1}$ rabbit anti-RBTMx in TBS-1\% nonfat dry milk, $0.05 \%$ Tween 20 for $1 \mathrm{~h}$. Blots were washed $4 \times$ in
$100 \mathrm{ml}$ of TBS with $0.05 \%$ Tween 20 . Blots were then incubated in mouse anti rabbit-HRP (Promega) at $0.2 \mu \mathrm{g} \mathrm{ml}^{-1}$ in TBS- $0.05 \%$ Tween 20 for $1 \mathrm{~h}$. The membranes were then washed $4 \times 10$ min in TBS-0.05\% Tween 20. Membranes were then incubated in $20 \mathrm{ml}$ of luminol substrate (Pierce, Rockford, IL, USA) for 10 min and exposed to Hyperfilm (Amersham. Arlington Heights, IL) autoradiography film for 1 to $5 \mathrm{~min}$.

Immunocytochemistry of poly I:C-induced RTG-2 cells. Following induction, monolayers were washed in ice-cold PBS and fixed for $20 \mathrm{~min}$ with $0.5 \mathrm{ml}$ of freshly prepared $3 \%$ paraformaldehyde in PBS. Cells were then permeabilized with $0.5 \mathrm{ml}$ of $0.1 \%$ Triton X-100 for 10 min, followed by 1 wash in PBS. The monolayers were blocked with $5 \%$ nonfat dry milk in PBS for $30 \mathrm{~min}$, then incubated with $0.5 \mathrm{ml}$ of $1 \mu \mathrm{g} \mathrm{ml} \mathrm{m}^{-1}$ antitrout $\mathrm{Mx}$ for $1 \mathrm{~h}$ at room temperature. The monolayer was washed $4 x$ in PBS for $5 \mathrm{~min}$ at each wash. The Vectastain rabbit ABC-AP kit (Vector Laboratories, Burlingame, CA, USA) was used for subsequent incubations according to the manufacturer's protocols with the exception that all washes were for $4 \times 5 \mathrm{~min}$ in PBS. The AP substrate kit III (Vector Laboratories), blue substrate, was used for detection, and incubation was carried out for 5 min for transfected cells or $2 \mathrm{~h}$ for poly $\mathrm{I}: \mathrm{C}$-induced cells, in the dark.

Immunohistochemistry of IHNV exposed rainbow trout. Assays were carried out as described by Drolet et al. (1994). Briefly, the tissue sections were deparaffinized by serial xylene and alcohol treatments and rehydrated for $10 \mathrm{~min}$ in distilled water. Sections were then equilibrated for $20 \mathrm{~min}$ in PBS (pH 7.4). The sections were blocked for $1 \mathrm{~h}$ with $5 \%$ powdered nonfat dry milk in PBS and then incubated with anti-Mx polyclonal antibody for $1 \mathrm{~h}$. The Vectastain-ABC rabbit IgG kit and the Vector-Red phosphate substrate (Vector Laboratories) were used to label and develop the sections. Sections were counterstained in hematoxylin for $1 \mathrm{~min}$ and $0.2 \%$ ammonium hydroxide in $70 \%$ ethanol solution for $30 \mathrm{~s}$. Sections were covered with Crystal Mount (Biomeda, Foster City, CA) and examined by light microscopy.

\section{RESULTS}

\section{Time course of Mx protein induction in RTG- 2 cells}

Experiments with Mx mRNA had previously shown that RTG-2 cells produce 2 transcripts discernible by gel analysis upon poly I:C dsRNA induction. These transcripts are first detectable at $24 \mathrm{~h}$ post induction, maximally expressed at $48 \mathrm{~h}$, and decrease in production at $72 \mathrm{~h}$ (Trobridge \& Leong 1995). The larger RNA band contained mRNA transcripts corresponding in 
size to that for RBTMx1, and the smaller RNA band contained 2 mRNA species encoding RBTMx2 and RBTMx3 respectively. To determine the time course of Mx protein expression in RTG- 2 cells after virus infection, RTG-2 cells were infected with IHNV (RB-4 isolate, MOI of 0.1 ) or poly I:C (for comparison) and then examined by immunoblots developed with polyclonal rabbit antisera generated to RBTMx3. Previous studies had shown that this antisera detected all 3 RBTMx proteins (Trobridge et al. 1997). After 24, 48, and $72 \mathrm{~h}$, the cells were lysed and extracts were made for immunoblot analysis. Two clearly discernible bands containing the $3 \mathrm{Mx}$ proteins (the upper band is a doublet) at approximately $70 \mathrm{kDa}$ were present in RTG-2 cells induced with poly I:C dsRNA but not in mockinduced controls or in IHNV-infected monolayers (Fig. 1). These sizes correspond to the in vitro translation products of RBTMx1, 2 and 3 (Trobridge et al. 1997).

The $\mathrm{Mx}$ proteins were first detected at $24 \mathrm{~h}$ post induction. Production appeared to be maximal at $48 \mathrm{~h}$ post induction, and there was still significant $\mathrm{Mx}$ protein present in the cell at $72 \mathrm{~h}$. A smaller band at approximately $50 \mathrm{kDa}$ was also detected in induced cells. Arnheiter et al. (1990) reported a breakdown product of murine $\mathrm{Mx} 1$ in immunoblots of poly $\mathrm{I}: \mathrm{C}$ induced $\mathrm{A} 2 \mathrm{G}$ mice and transgenic mice. The predominant breakdown product was approximately $50 \mathrm{kDa}$. We suggest that the $50 \mathrm{kDa}$ band in induced RTG-2 cells is a breakdown product since it accumulates over time and is expressed only in induced cells. Whether or not this putative breakdown product is related to the murine $50 \mathrm{kDa}$ protein reported by Arnheiter et al. (1990) is unknown. The band at $58 \mathrm{kDa}$ in the $48 \mathrm{~h}$ samples must be a host protein since it was found in all 3 samples: control, virus-infected, and poly I:C induced.

\section{Immunocytochemistry of Mx protein expression in RTG-2 cells}

The in situ expression of Mx protein in RTG-2 cells was assessed by immunocytochemical staining of cells treated with either 5 or $50 \mu \mathrm{g} \mathrm{ml}^{-1}$ of poly I:C dsRNA. Mock-induced cells received only culture medium. At 24 and $48 \mathrm{~h}$ the cells were fixed and stained with anti$\mathrm{Mx}$ polyclonal sera (Fig. 2). A quantity of $5 \mu \mathrm{g} \mathrm{ml}^{-1}$ poly $\mathrm{I}: \mathrm{C}$ dsRNA was sufficient to induce detectable differences in $\mathrm{Mx}$ protein expression. Fifty $\mu \mathrm{g} \mathrm{ml}^{-1}$ poly I:C also resulted in $\mathrm{Mx}$ induction, but at this concentration toxicity was evident after $24 \mathrm{~h}$. To detect endogenous Mx protein in poly I:C-induced RTG-2 cells using this method, long substrate incubation times of up to $2 \mathrm{~h}$ were required and, as a result, there was some background staining. However, clear differences are seen between controls and poly I:C-induced cells.

\section{Induction of $\mathrm{Mx}$ protein in vivo}

We had previously shown IHNV to be a potent inducer of Mx mRNA in vivo (Trobridge \& Leong 1995). With a highly virulent strain of IHNV, this induction of Mx mRNA occurs in up to $99 \%$ of fish injected with virus (authors' unpubl. data). We chose to evaluate IHNV induction of Mx protein in vivo by immersing trout fry in a high concentration of a viral isolate that causes up to $100 \%$ mortality. Controls were immersed in MEM-0 alone. At time 0, 2, and $4 \mathrm{~d}$ fish were collected and kidneys and livers were analyzed by immunoblot for $\mathrm{Mx}$ induction and for IHNV protein production. At $2 \mathrm{~d}$ post infection some infected fish were moribund, and at $4 \mathrm{~d}$ the remaining infected fish were either moribund ( 5 fish) or dead ( 9 fish). Four of the remaining 5 moribund fish were sampled and the

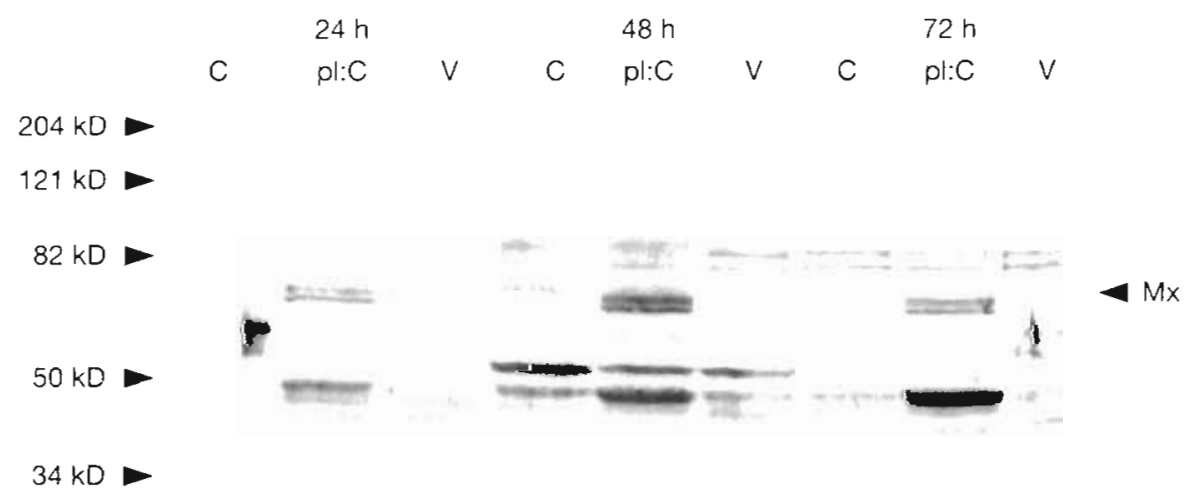

Fig. 1. Induction of RTG-2 Mx protein by poly I:C dsRNA. RTG-2 monolayers were mock induced (C). induced with $50 \mu \mathrm{g} \mathrm{mI}^{-1}$ poly I:C dsRNA (pI:C), or treated with IHNV at an MOI of $0.1(\mathrm{~V})$ for 24,48 , and $72 \mathrm{~h}$ and analyzed by immunoblot for Mx protein. Molecular weights are indicated on the left as determined by prestained MW markers. The arrow on the right side of the blot indicates the triplet band of expressed $\mathrm{Mx}$ protein at approximately $70 \mathrm{kDa}$ 


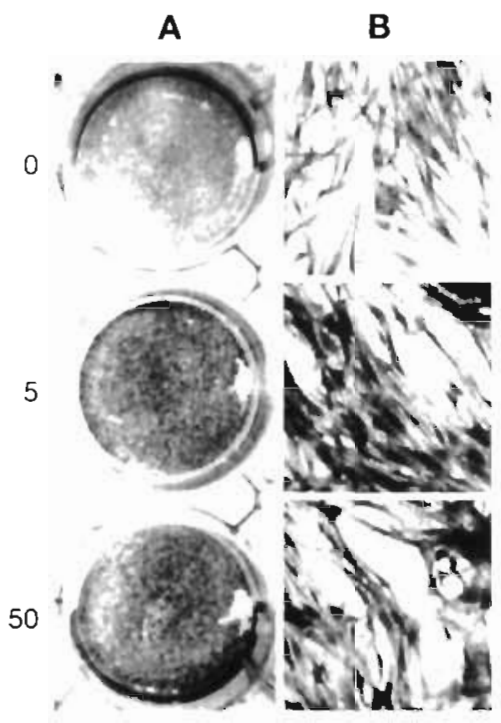

Fig. 2. Induction of RTG-2 endogenous $\mathrm{Mx}$ by poly I:C dsRNA. RTG-2 cells were mock induced with MEM-0 (0) or induced with 5 or $50 \mu \mathrm{g} \mathrm{ml}^{-1}$ poly I:C dsRNA (5 and 50, respectively) for $48 \mathrm{~h}$ and analyzed for $\mathrm{Mx}$ protein in duplicate using immunocytochemistry. (A) Photograph of 1 row of the multiwell plate; (B) magnification of the RTG-2 cells of (A)

Darker staining indicates $\mathrm{Mx}$ expression

experiment was terminated. All livers and kidneys were analyzed by immunoblot. All kidney and liver tissues from the infected fish showed evidence of IHNV protein production. $M x$ protein was first detected in the kidney of fish at $2 \mathrm{~d}$ post exposure. None of the control, mock-infected fish expressed $\mathrm{Mx}$
Table 1. Induction of Mx protein in rainbow trout challenged with IHNV Rainbow trout, average weight $2.2 \mathrm{~g}$, were immersed in tissue culture supernatant (mock challenged) or in culture media containing $10^{5} \mathrm{TCID}_{50}$ units of IHNV (Rangen) (IHNV challenged). The fish were assayed for Mx protein by western blot at the indicated time points. The number of fish expressing Mx over number of fish examined are represented for each time point for both kidney and liver tissues

\begin{tabular}{|c|c|c|c|c|}
\hline & \multicolumn{2}{|c|}{ Mock challenged } & \multicolumn{2}{|c|}{ IHNV challenged } \\
\hline & Kidney & Liver & Kidney & Liver \\
\hline Time 0 & $0 / 4$ & $0 / 4$ & $0 / 4$ & $0 / 4$ \\
\hline Day 2 & $0 / 4$ & $0 / 4$ & $2 / 4$ & $0 / 4$ \\
\hline Day 4 & $0 / 4$ & $0 / 4$ & $4 / 4$ & $3 / 4$ \\
\hline
\end{tabular}

protein. The data are summarized in Table 1. The immunoblots of tissues examined on Day 4 are shown in Fig. 3. At Day 4, the kidney extracts of the 4 IHNVtreated fish contained $\mathrm{Mx}$ protein bands at approximately $70 \mathrm{kDa}$, as well as the $50 \mathrm{kDa}$ putative $\mathrm{Mx}$ breakdown protein. The kidney of Fish 2 (K2 in Fig. 3) was also positive for $\mathrm{Mx}$ production in blots that contained more extract (data not shown). Mx protein was detected in the livers of 3 of the 4 fish examined (lanes L1-4 in Fig. 3). The control fish also taken on Day 4 showed no detectable bands at $70 \mathrm{kDa}$ or $50 \mathrm{kDa}$. IHNV-challenged Fish 4 liver and kidney samples were subjected to electrophoresis on the same blot to compare sizes and amounts of Mx protein. Both kidney and liver contained 2 discernable $\mathrm{Mx}$ bands of approximately $70 \mathrm{kDa}$ and the putative $50 \mathrm{kDa}$ breakdown product.
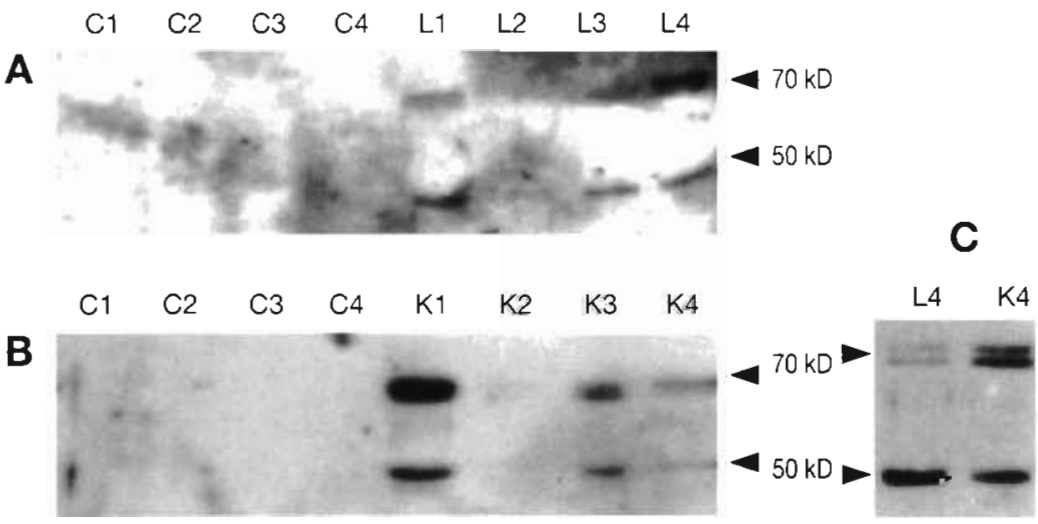

Fig. 3. Induction of $\mathrm{Mx}$ protein in rainbow trout liver (L) and kidney (K). Rainbow trout were infected by immersion with IHNV (Rangen) or by mock immersion in tissue culture supernatant (control ${ }_{i}$ C). At time 0, Day 2, and Day 4 post injection, liver and kidney tissue was analyzed by western blot for expression of Mx protein. These blots show the Day 4 results of (A) liver and (B) kidney for controls and Fishes 1-4 and (C) Fish 4 liver and kidney proteins separated by electrophoresis and transferred to nitrocellulose. Molecular weights were estimated with prestained markers. The arrows on the right of each panel show the $70 \mathrm{kDa} \mathrm{Mx}$ protein and the putative $50 \mathrm{kDa}$ breakdown product

\section{Immunohistochemistry of Mx protein in trout}

The immunohistochemical staining for the Mx protein in IHNV RB-76infected fish showed positive red staining in the kidney tubules (Fig. 4). Conversely, kidney tissues of the negative control fish showed no red staining. The kidney tissues taken from the IHNV-infected fish at $2 \mathrm{~d}$ post exposure showed signs of necrosis and damage from virus infection, whereas the negative control fish showed only healthy undamaged kidney tubules. At least 3 whole-body serial sections from each fish were stained for Mx protein. The tissues of the liver, stomach, intestine, and pyloric caecae were positively stained for $\mathrm{Mx}$ in some, but not all, fish examined (data not shown). 

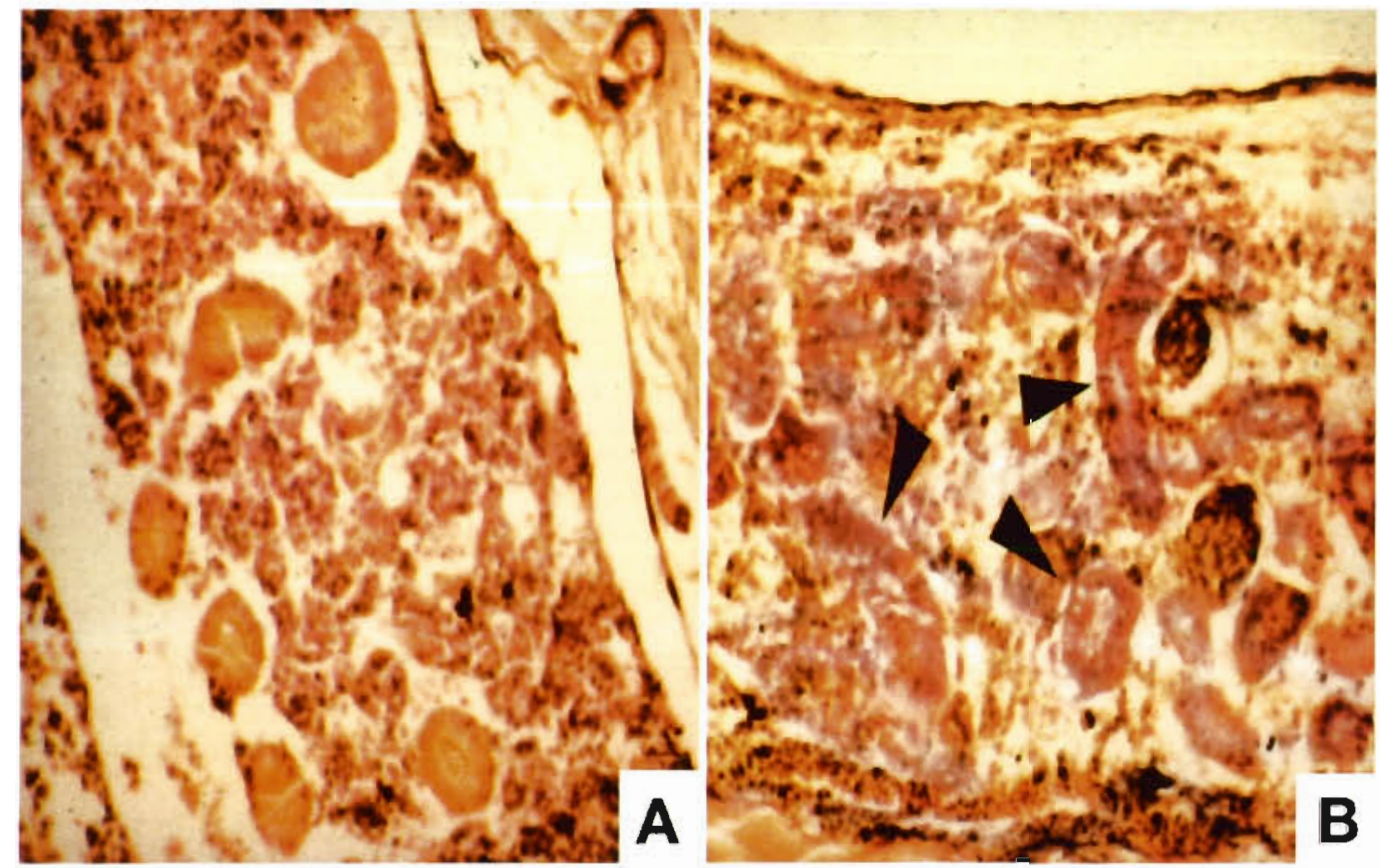

Fig. 4. Immunohistochemical staining of infected fish tissue for Mx. Kidney tissue from (A) an uninfected fish and (B) a fish infected with RB-76 stained with a polyclonal antibody directed against Mx. Kidney tissues were examined with a $20 \times(200 \times$ total magnification) objective lens. Dark red staining in (B) indicates the presence of $\mathrm{Mx}$ protein in the kidney tubules and is indicated by arrows

\section{DISCUSSION}

Rainbow trout Mx mRNA is rapidly and transiently induced by the IFN inducer poly I:C dsRNA and by injection of virus in vivo (Staeheli et al. 1989, Trobridge \& Leong 1995). There is currently no available anti-fish IFN antibody and no highly purified source of fish IFN. Until these reagents become available it is impossible to show the direct induction of $\mathrm{Mx}$ protein by IFN. We characterize here the induction of trout $\mathrm{Mx}$ protein in vitro by poly I:C dsRNA and in vivo by immersion challenge with IHNV. The data presented here establish the use of trout $\mathrm{Mx}$ protein as a marker for an interferon-like response in fish.

Trout Mx protein was detected by western blot in RTG-2 cells induced by poly I:C dsRNA treatment. Three protein bands of approximately $70 \mathrm{kDa}$ were first seen $24 \mathrm{~h}$ post induction with $50 \mu \mathrm{g} \mathrm{ml}^{-1}$ poly I:C dsRNA. The Mx protein peaked at $48 \mathrm{~h}$, and declined at $72 \mathrm{~h}$ post induction with $50 \mu \mathrm{g} \mathrm{m}^{-1}$ poly I:C dsRNA. The sizes of the induced $M x$ proteins correspond to the sizes of the proteins produced by the 3 cloned RTG-2 $\mathrm{Mx}$ genes in in vitro transcription/translation reactions (RBTMx1-71 kDa, RBTMx2-69 kDa, RBTMx3-72 kDa) (Trobridge et al. 1997). Interestingly, IHNV infection did not produce significant amounts of $\mathrm{Mx}$ protein in RTG-2 cells. We had previously been unable to induce $\mathrm{Mx}$ mRNA in vitro by IHNV infection (authors' unpubl. obs.) while IHNV injection induces Mx mRNA in vivo at up to $99 \%$ efficiency (Trobridge unpubl. obs.). We reason that the induction of IFN in RTG-2 cells is not as efficient as in fish tissues, where the presence and interaction of several cell types might lead to more potent induction of IFN.

Endogenous Mx protein of RTG-2 cells was detected by immunocytochemistry in the cytoplasm and nucleus after induction by poly I:C dsRNA. Immunohistochemical staining revealed $\mathrm{Mx}$ protein in the cytoplasm and nucleus. Mx protein was induced at both 5 and $50 \mu \mathrm{g} \mathrm{ml}^{-1}$ poly I:C dsRNA after $48 \mathrm{~h}$, although some cytotoxicity was evident in the $50 \mu \mathrm{g} \mathrm{ml}^{-1}$ poly I: C dsRNA induced wells. The amount of $\mathrm{Mx}$ produced endogenously was lower than that achieved previously when plasmid DNA encoding the Mx protein was transfected into CHSE-214 cells (Trobridge et al. 1997). Longer incubation times with substrate were required to see a difference between control and poly I:Ctreated wells; and, consequently, the background was higher in these studies.

The induction of $\mathrm{Mx}$ protein in vivo was examined using immunoblotting of tissue extracts from fish challenged with IHNV via immersion. Mx protein was induced in all kidney tissues of fish examined at $4 \mathrm{~d}$ post infection with a high concentration of virulent IHNV. No Mx was detected in uninfected controls. This preliminary experiment suggests that $\mathrm{Mx}$ protein may be 
a consistent marker for infection with IHNV. It is possible that Mx protein may be useful as a marker for other fish viral infections and might be used to classify fish diseases of unknown etiology as viral. Mammalian Mx protein is tightly regulated by an IFN alpha/beta cytokine profile during viral infections (Aebi et al. 1989, von Wussow et al. 1990, Simon et al. 1991).

To establish the sites of $\mathrm{Mx}$ protein expression, we infected rainbow trout fry by immersion exposure to the RB-76 isolate of IHNV. In a study by Drolet et al. (1994), the progression of IHNV through the body of infected fish was determined by immunohistochemistry. The study showed 2 routes of infection: one through the oral cavity and another through the gill epithelium into the circulatory system. In the latter route, the gill epithelium was the first tissue to be infected, followed by the lamellar and filament endothelium. IHNV was later found in the dorsal aorta, and finally the kidney tissue was infected via the renal arteries. Strong positive staining for viral antigen in the kidney tubules was seen. In addition, Drolet et al. were able to detect viral antigen in the tissues of the gill, kidney, thymus, spleen, pyloric caecum, liver, and intestine. $\mathrm{Mx}$ protein was detected consistently in the kidney tubules. Mx was also detected in the gill, kidney, thymus, spleen, pyloric caecum, liver, and intestine of some fish. The expression of $\mathrm{Mx}$ in the kidney suggests that IHNV replication in the tubule epithelium induced IFN, and subsequently $M x$ protein. Double label experiments with virus antisera and antiMx sera may help us to find out where and when the virus is replicating, and where IFN is being produced.

Several characteristics make the $\mathrm{Mx}$ proteins ideal markers for IFN. Mx proteins are rapidly and transiently induced specifically by type I IFNs in mammals. More importantly, unlike IFN, Mx is produced in large amounts and has a long half-life. $\mathrm{Mx}$ in induced cells can comprise up to $1 \%$ of the total cytoplasmic protein (Horisberger 1992) and has a biological half-life of $2.5 \mathrm{~d}$ (Ronni et al. 1993). Moreover, cellular induction of $\mathrm{Mx}$ protein is not subject to feedback inhibition even at high doses of IFN therapy (von Wussow et al. 1990). Immunoassays have been developed to detect human Mx in blood (Towbin et al. 1992, Oh et al. 1994), and Mx has been used as a marker for IFN therapy (Jakschies et al. 1990). Because of these properties, mammalian $\mathrm{Mx}$ protein has been used in several studies as a marker for type I IFN (Kraus et al. 1992, Yamada et al. 1994, Abrams et al. 1995). Roers et al. (1994) used the presence of $\mathrm{Mx}$, and therefore type I IFN, to assess vaccination efficacy of attenuated yellow fever virus in volunteers. In this study unvaccinated volunteers produced 50 -fold more $\mathrm{Mx}$ protein than previously vaccinated volunteers upon infection with the 17-D strain of yellow fever virus. This suggested that successfully vaccinated individuals had enough circulating antibody to clear the virus before IFN was induced, and therefore the induction of $\mathrm{Mx}$ synthesis by IFN was not seen. The presence or absence of $\mathrm{Mx}$ protein was used as an indicator of whether or not vaccination was successful. Such an inventive use of the trout Mx as an IFN marker may provide a powerful method to evaluate fish viral vaccine efficacy.

Acknowledgements. This paper reports a portion of the work described in a thesis submitted to Oregon State University Department of Microbiology in partial fulfillment of the requirements for a PhD degree. The authors thank Dr Dan Mourich for his advice on experimental protocols. This research was supported by the United States Department of Agriculture to the Western Regional Aquaculture Consortium under grant 92-38500-7195, project no. 92080441; an Oregon Sea Grant with funds from the National Oceanic and Atmospheric Administration, Office of Sea Grant, Department of Commerce, under grant NA89AA-D-SG108, project R/FSD16, and grant NA36RG451, project R/FSD-23 and Amendment. No. 2; and a grant from the National Oceanic and Atmospheric Administration (Saltonstall-Kennedy funds), NA46FD0490. Oregon Agricultural Experiment Station Technical Paper No. 11,086.

\section{LITERATURE CITED}

Abrams ME, Balish MJ, Brandt CR (1995) IFN-alpha induces MxA gene expression in cultured human corneal fibroblasts. Exp Eye Res 60:137-142

Aebi M, Fah J, Hurt N, Samuel CE, Thomis D, Bazzigher L, Pavlovic J, Haller O, Staeheli P (1989) cDNA structures and regulation of two interferon-induced human $\mathrm{Mx}$ proteins. Mol Cell Biol 9:5062-5072

Arnheiter H, Meier E (1990) Mx proteins: antiviral proteins by chance or by necessity? New Biol 2:851-857

Arnheiter H, Skuntz S, Noteborn M, Chang S, Meier E (1990) Transgenic mice with intracellular immunity to influenza virus. Cell 62:51-61

Beasley AR, Sigel MM (1967) Interferon production in coldblooded vertebrates. In Vitro 3:154-165

Broni B, Julkunen I, Condra HH, Davies ME, Berry MJ, Krug RM \{1990\} Parental influenza virion nucleocapsids are efficiently transported into the nuclei of murine cells expressing the nuclear interferon-induced $\mathrm{Mx}$ protein J Virol 64:6335-6340

de Kinkelin P, Dorson M (1973) Interferon production in rainbow trout (Salmo gairdneri, Richardson) experimentally infected with Egtved virus. J Gen Virol 19:125-127

de Sena J, Rio GJ (1975) Partial purification and characterization of RTG-2 fish cell interferon. Infect Immun 11: 815-822

Drolet BS, Rohovec JS, Leong JC (1994) The route of entry and progression of infectious hematopoietic necrosis virus in Oncorhynchus mykiss: a sequential immunohistochemical study. J Fish Dis 17:337-347

Eaton WD (1990) Anti-viral activity in four species of salmonids following exposure to poly inosinic:cytidylic acid Dis Aquat Org 9:193-198

Frese M, Kochs G, Geldmann H, Hertkorn C, Haller O (1996) Inhibition of bunyaviruses, phleboviruses, and hantaviruses by human MxA protein. J Virol 70:913-923 
Frese M, Kochs G, Meier-Dieter U, Siebler J, Haller O (1995) Human MxA protein inhibits tick-borne Thogoto virus but not Dhori virus. J Virol 69:3904-3909

Fryer JL, Yusha A, Pilcher KS (1965) The in vitro cultivation of tissue and cells of Pacific salmon and steelhead trout. Ann NY Acad Sci 126:566-586

Gravell M, Marlsberger RG (1965) A permanent cell line from fathead minnow (Pimephales promelas). Ann NY Acad Sci 126:555-565

Horisberger MA (1992) Interferon-induced human protein MXA is a GTPase which binds transiently to cellular proteins. J Virol 66:4705-4709

Horisberger MA, Haller $O$, Arnheiter $H$ (1980) Interferon dependent genetic resistance to influenza virus in mice: virus replication in macrophages is inhibited at an early step. J Gen Virol 50:205-210

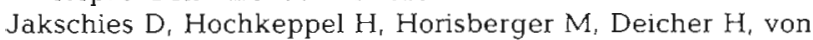
Wussow P (1990) Emergence and decay of the human Mx homolog in cancer patients during and after interferonalpha therapy. J Biol Response Modif 9:305-312

Koromilas AE, Roy $\mathrm{S}$, Barber GN, Katze MG, Sonenberg N (1992) Malignant transformation by a mutant of the IFNinducible dsRNA-dependent protein kinase. Science 257 : $1685-1689$

Kraus E, Schneider-Schaulies S, Miyasaka M, Tamatani T, Sedgwick J (1992) Augmentation of major histocompatibility complex class I and ICAM- 1 expression on glial cells following measles virus infection: evidence for the role of type 1 interferon. Eur J Immunol 22:175-182

Krug RM, Shaw M, Broni B, Haller O (1985) Inhibition of influenza viral mRNA synthesis in cells expressing the interferon-induced Mx gene product. J Virol 56:201-206

MacDonald RD, Kennedy JC (1979) Infectious pancreatic necrosis virus persistently infects chinook salmon embryo cells independent of interferon. Virology 95:260-264

Meier E, Kunz G, Haller O, Arnheiter H (1990) Activity of rat $\mathrm{Mx}$ proteins against a rhabdovirus. J Virol 64:6263-6269

Melen K, Julkunen I (1994) Mutational analysis of murine Mx1 protein: GTP binding core domain is essential for anti-influenza activity. Virology 205:269-279

Meurs E, Chong K, Galabru J, Thomas NS, Kerr IM, Williams BR, Hovanessian AG (1990) Molecular cloning and characterization of the human double-stranded RNA-activated protein kinase induced by interferon. Cell 62:379-390

Meyer T, Horisberger MA (1984) Combined action of mouse alpha and beta interferons in influenza virus-infected macrophages carrying the resistance gene Mx. J Virol 49: $709-716$

Oh SK, Luhowskyj S, Witt P, Ritch P, Reitsma D, Towbin H, Horisberger $M$, von Wussow P. Bluestein B (1994) Quantitation of interferon-induced $\mathrm{Mx}$ protein in whole blood lysates by an immunochemiluminescent assay: elimination of protease activity of cell lysates in toto. J Immunol Meth 176:79-91

Oie HK, Loh PC (1971) Reovirus Type 2: induction of viral resistance and interferon production in fathead minnow cells. Proc Soc Exp Biol Med 136:369-373

Pavolovic J, Schroder A, Blank A, Pitossi F, Staeheli P (1993) Mx proteins: GTPases involved in the interferon-induced antiviral state. Ciba Found Symp 176:233-243

Responsible Subject Editor: Larry Vaughan, Dublin, Ireland
Pitossi FJ, Blank A, Schroder A, Schwarz A, Hussi P, Schwemmle M, Pavolovic J, Staeheli P (1993) A functional GTP binding motif is necessary for antiviral activity of $\mathrm{Mx}$ proteins. J Virol 67:6726-6732

Roers A, Hochkeppel HK, Horisberger MA, Hovanessian A, Haller O (1994) MxA gene expression after live virus vaccination: a sensitive marker for endogenous type I interferon. J Infect Dis 169(4):807-813

Ronni T, Melen K, Malygin A, Julkunen I (1993) Control of IFN-inducible MxA gene expression in human cells. J Immunol 150:1715-1726

Sano T, Nagakura Y (1982) Studies on viral diseases of Japanese fishes-VIII. Interferon induced by RTG-2 cell infected with IHN virus. Fish Pathol 17:179-185

Schneider-Schaulies S, Schneider-Schaulies J, Schuster A, Bayer M, Pavlovic J, Ter Meulen V (1994) Cell typespecific MXA-mediated inhibition of measles virus transcription in human brain cells. J Virol 68:6910-6917

Simon A, Fah J, Haller O, Staeheli P (1991) Inteferon-regulated $\mathrm{Mx}$ genes are not responsive to interleukin-1, tumor necrosis factor, and other cytokines. J Virol 65:968-971

Staeheli P, Haller O (1987) Inteferon-induced Mx protein: a mediator of cellular resistance to influenza virus. Interferon 8:1-23

Staeheli P, Haller O, Boll W, Lindenmann J, Weissmann C (1986) Mx protein: constitutive expression in 3T3 cells transformed with cloned $\mathrm{Mx}$ cDNA confers selective resistance to influenza virus. Cell 44:147-158

Staeheli P, Yu YX, Grob R, Haller O (1989) A double-stranded RNA-inducible fish gene homologous to the murine influenza virus resistance gene $\mathrm{Mx}$. Mol Cell Biol 9: $3117-3121$

Tengelsen LA, Anderson E, Leong J (1989) Variation in fish interferon-like activity: cell line production and IHN virus isolate sensitivity. Fish Health Soc Am Fish Soc Newsl $17: 4$

Thimme R, Frese M, Kochs $G$, Haller O (1995) Mx1 but not MxA confers resistance against tick-borne Dhori virus in mice. Virol 211:296-301

Towbin H, Schmitz A, Jakschies D, von Wussow P, Horisberger MA (1992) A whole blood immunoassay for the interferon-inducible human $\mathrm{Mx}$ protein. J Interfer Res $12: 67-74$

Trobridge GD, Chiou PP, Leong JC (1997) Cloning of the rainbow trout (Oncorhynchus mykiss) Mx2 and Mx3 cDNAs and characterization of trout $\mathrm{Mx}$ protein expression in salmon cells. J Virol 71:5304-5311

Trobridge GD, Leong JC (1995) Characterization of a rainbow trout Mx gene. J Interferon Cytokine Res 15:691-702

von Wussow P, Jakschies D, Hochkeppel HK, Fibich C, Penner L, Deicher $\mathrm{H}$ (1990) The human intracellular Mxhomologous protein is specifically induced by type 1 interferons. Eur J Immunol 20:2015-2019

Wolf K, Quimby MC (1962) Established eurythermic line of fish cells in vitro. Science 135:1065-1066

Yamada T, Horisberger MA, Kawaguchi N, Moroo I, Toyoda T (1994) Immunohistochemistry using antibodies to alpha interferon and its induced protein, MxA, in Alzheimer's and Parkinsons disease brain tissues. Neurosci Lett 181. $61-64$

Manuscript received: December 6, 1996 Revised version accepted: June 10,1997 